\title{
Van wreed naar werkbaar optimisme: bestuurskunde in transitie
}

\author{
Mirko Noordegraaf
}

\section{Inleiding}

La Grouw heeft een interessant en relevant stuk geschreven. Om twee redenen. Ten eerste zit het stuk vol gevoel, ervaring en perceptie, en in die zin gaat het ergens over. Namelijk hoe het voelt om als jonge onderzoeker in onze hedendaagse bestuurskunde te opereren. Ten tweede zit het stuk vol kritische analyse, en het is niet alleen mooi dat een jonge onderzoeker de wereld om haar heen analyseert - het is mooi dat een jonge onderzoeker het 'jonge onderzoeker'-zijn analyseert. Mooi, en belangrijk!

Maar, aan de gevoelens alsmede de kritische analyse zitten wel wat haken en ogen. Ik zou het kunnen hebben over de gevoelens, in zekere zin de zeer existentiele gevoelens, die in La Grouws stuk benadrukt worden, en dan zou ik benadrukken dat het doormaken van een PhD-traject altijd een dosis flinke existentiële twijfel en onzekerheid genereert. Dat is van alle tijden.

Ik zou het ook kunnen hebben over het paradoxale feit dat La Grouw's discoursanalyse van jonge onderzoekers in relatie tot senior onderzoekers nogal strikte discursieve distincties fixeert - zoals tussen 'junior' en 'senior' - en daarmee automatisch asymmetrie en oppositie bestendigt - 'junior versus senior'. Die distincties zijn weinig behulpzaam.

Maar dat doe ik allemaal niet. Wel wil ik enkele basisassumpties in haar stuk blootleggen en die kritisch bespreken. Want La Grouw neemt via haar gevoelens en analyse een aantal zaken voor 'waar' aan, en ik denk dat dit riskant is. Vooral omdat de gewenste uitweg of 'oplossing' daarmee niet dichterbij komt. Integendeel. Ik zie drie assumpties in haar artikel, en die ga ik hieronder kritisch bespreken:

- La Grouw ziet vooral problemen en lasten, terwijl er veel mogelijkheden zijn, omdat we als bestuurskundig veld in beweging zijn. Het is geen zware, maar een spannende tijd!

- La Grouw denkt dat senior vakgenoten, inclusief hoogleraren in positie die bazen zijn, 'echt' de baas zijn. Wij als bazen zijn (vaak) helemaal niet de baas!

- La Grouw heeft veel kritiek op het systeem, waar die bazen te weinig aan en mee doen, terwijl dat systeem veel ruimte en marge kent, ook voor jonge onderzoekers. Pak die ruimte!

* Prof. dr. Mirko Noordegraaf is hoogleraar publiek management, departement Bestuurs- \& Organisatiewetenschap (USBO), vicedecaan maatschappelijke impact, faculteit Recht, Economie en Bestuur \& Organisatie (REBO), Universiteit Utrecht, en voorzitter van de Vereniging voor Bestuurskunde (VB). 


\section{Wetenschap is (en blijft) in beweging!}

We kunnen niet ontkennen dat er druk zit op de bestuurskunde, inclusief druk op jonge bestuurskundig onderzoekers. Dat is deels prestatie- en publicatiedruk, maar ook meer fundamentele druk: wat is (de) bestuurskunde tegenwoordig?

Ooit was dat simpel, bestuurskunde was 'de leer van de inrichting en werking van het openbaar bestuur'. (Zo stond dat letterlijk in de studiegidsteksten toen ik zelf in Rotterdam studeerde, tussen 1988-1993.) Tegenwoordig zijn we veel minder government georiënteerd, en leggen we veel meer nadruk op governance, in het licht van maatschappelijke vraagstukken. Dat betekent dat we minder 'eigenheid' hebben. Deels omdat 'governance' overheidsactie impliceert, maar tevens acties van niet-overheidsorganisaties. Deels omdat maatschappelijke vraagstukken multidisciplinair zijn, en niet via een discipline te begrijpen en in de greep te houden zijn. Dit is eigenlijk heel paradoxaal. Bestuurskunde is relevanter dan ooit, maar minder herkenbaar en meer verspreid dan ooit - verspreid door organisatorische en disciplinaire velden.

Dat betekent dat we er meer dan ooit voor moeten zorgen dat we 'ertoe doen'. Dat doen we op allerlei manieren via de inhoud, via de juiste thema's, projecten en samenwerkingen, maar dat moeten we tevens institutioneel doen. Dat laatste impliceert dat we mee moeten 'tellen' - letterlijk en figuurlijk - in de institutionele regimes, variërend van de Nederlandse Organisatie voor Wetenschappelijk Onderzoek (NWO) via European Research Council ERC tot journals en H-indices. Het verklaart ook een zekere 'verharding' van ons vakgebied, bijvoorbeeld als het gaat om koppelingen met de gedragseconomie en psychologie, zoals in de 'gedragsbestuurskunde' gebeurt.

Tegelijkertijd moeten we deze ontwikkelingsgang relativeren. We hebben als vakgebied een vrij mild publicatieregime (mede via de onderzoeksschool NIG bewaakt), en we hebben een plek in de nadruk op gedifferentieerde 'publicatieculturen' in en via de NWO. Bovendien zijn er bredere bewegingen gaande waar we baat bij hebben: de Nationale Wetenschapsagenda, Science in Transition, Open Science, en daar haken allerei bestuurskundigen op aan. Tot slot hebben wij mogelijkheden om onszelf te versterken. We kunnen zichtbaar zijn en blijven, inverdienmogelijkheden in de gaten houden en gebruiken, en partnerships vormen en daar coproducties mee vormgeven. We kunnen 'hybride PhD's' aan de slag laten gaan, PhD's die bij partners werken, maar tevens promotietijd hebben. Dat biedt allerlei mogelijkheden voor jonge onderzoekers om betekenisvol onderzoek doen.

Dat gaat natuurlijk niet vanzelf en in die zin is wetenschappelijke actie sowieso minder vanzelfsprekend geworden. We moeten meer werk maken van hoe we werk maken - we moeten actief op zoek naar kansen en constructies, via de geëigende kanalen zoals de NWO en ERC, maar ook daarbuiten. Dat brengt onzekerheden met zich, niet alleen voor jongere, maar tevens voor meer senior wetenschappers! Daar hoort de taak bij om jongere onderzoekers veilige plekken en houvast te geven en hen niet enkelvoudig 'af te rekenen', maar alle betrokkenen werken in een minder vanzelfsprekende, minder gegarandeerde omgeving. Dat gaat niet 
zozeer om publicatiedruk, maar veel meer om maatschappelijke druk en de noodzaak om relevante, aansprekende en verbonden wetenschap te genereren. Die bredere transitie, daar moeten we het vooral over hebben, en daar staan we samen voor. (Overigens niet alleen in de academische bestuurskunde, ook in de meer praktische bestuurskunde, merk ik als voorzitter van de Vereniging voor Bestuurskunde.)

\section{'Bazen' zijn niet zonder meer 'de baas'!}

In het stuk van La Grouw zitten - hoe mooi ook verwoord - enkele verwijten, vooral richting de seniors die het voor het zeggen hebben, 'de baas' zijn, en een aantal steken laten vallen. Dat moeten we ons aantrekken, en we kunnen altijd leren van hoe we dingen aanpakken. Dat is belangrijk. Maar de bazen zijn vaak helemaal niet de baas... Dat geldt voor ervaren hoogleraren, voor afdelingsvoorzitters en hoofden departement, voor decanen en zelfs voor leden van de Colleges van Bestuur. Natuurlijk zijn ze strikt genomen de baas, omdat ze leidinggeven aan mensen en/of omdat ze naast managerial vooral ook bestuurlijke verantwoordelijkheden hebben. Ze kunnen koers bepalen, richting uitzetten, dossiers verder brengen, beslissingen forceren, en noem maar op. Maar toch.

Hun baas-zijn is en wordt flink ingetoomd door interne en externe institutionele krachten. Dat gaat dan bijvoorbeeld over medezeggenschap, op alle niveaus, en over toezicht via de Raad van Toezicht. Het gaat intern vooral ook om stafdiensten, humanresources, financial control, et cetera, en meer extern geldt het voor de accountantscontrole, die bovendien steeds interner en indringender geworden is. Nog meer extern gaat het over inspectie, via de Inspectie, beleidsinkadering en (prestatie)akkoorden, en over de bekostiging van hoger onderwijs.

Dit is geen verhaal om tekortkomingen van leidinggevenden, managers en bestuurders weg te redeneren. Integendeel, het vraagt des te meer iets van de bazen, en daar moeten ze goed voor worden opgeleid en geëquipeerd. Het is vooral een verhaal om duidelijk te maken dat juniors en seniors in eenzelfde soort schuitje zitten en vergelijkbare dwingende en vooral dubbele krachten ervaren. Bestuurlijk wordt best duidelijk gesproken over 'minder werkdruk', 'minder regels', 'meer vertrouwen' en zelfs 'ontzorgen' van medewerkers (bah!), maar ondertussen wordt de boel meer dan ook strikt ingekaderd en in de gaten gehouden. Hoe komt dat? Toch mede dankzij maatschappelijke invloeden. Journalistiek en politiek staan gevestigde machten onder druk, bestuurders liggen onder een vergrootglas (bijvoorbeeld qua declaratiegedrag), en gegeven gezag staat onder druk. Dat we de pretstatieteugels aanhalen - moeten aanhalen... - is dan onvermijdelijk, hoe zeer het tevens onmogelijk is.

Het is voor de komende jaren van groot belang dat we deze klem verminderen. Dat doen we door bij te dragen aan maatschappelijk debat, door bestuurlijke verantwoordelijkheid te nemen, waar mogelijk, en door de handen ineen te slaan. Het vakgebied zal zich sterker moeten profileren, bijvoorbeeld via het Disciplineoverleg Bestuurskunde en de onderzoeksschool NIG, in relatie tot de Koninklijke 
Nederlandse Akademie van Wetenschappen en de sectorontwikkelingen (in het bijzonder de sector Social Sciences \& Humanities). In de nieuwe fase van de NIG kunnen we dan de 'verspreiding' van de bestuurskunde op nieuwe manieren vorm en inhoud geven - mede in relatie tot de Vereniging voor Bestuurskunde, waar mogelijk - en kunnen we nieuwe manieren vinden om ons gezag te versterken. Dit alles is een primaire verantwoordelijkheid voor 'de bazen'.

\section{'Het systeem' is niet alomvattend!}

Hoewel we omringd worden door dwingende machten en krachten, en de macht van 'het systeem' ervaren, moeten we ook weer oppassen voor het te dominant maken van 'het systeem', dat vervolgens de 'leefwereld' van professionals beklemt en disciplineert. Het systeem is relatief en te bespelen, en daarbinnen zijn ruimtes en marges te organiseren. Dat is niet vooral alles een zaak van/voor het vakgebied, waar ik het hiervoor over had, maar voor departementen c.q. instituten op instellingsniveau. Dat gebeurt de facto ook, hoewel van plek tot plek verschilt hoe dat ervoor staat. Maar als departementen/instituten ervoor zorgen dat ze goede mensen aantrekken, financieel gezond zijn, gedoseerd en betekenisvol sturen, vitale departementale klimaten stimuleren, medewerkers meervoudig aanspreken (op meerdere prestaties), en als ze zowel academische als maatschappelijke verantwoordelijkheden voor ogen houden en waarmaken, dan genereert dat gezonde bestuurskundige omgevingen.

Ook dat hebben we ter plekke niet zomaar in de hand en is mede afhankelijk van de bredere universitaire omgeving, maar toch, ons bereik is best groot. Het gaat aangaande jonge onderzoekers dan bijvoorbeeld over de vraag hoe ze qua begeleiding worden ingebed, welke mogelijkheden ze krijgen om zich verder te ontwikkelen - naast hun onderzoekontwikkeling - en welke netwerken ze intern en extern vormen. Van belang lijkt mij bijvoorbeeld het blijvend faciliteren van de combinatie van 'hardcore' onderzoek met onderwijs en impact, alsmede het werken aan de academische 'employability', bijvoorbeeld via het behalen van je basiskwalificatie onderwijs. Het werken aan een PhD-traject draait ten slotte niet alleen om het sec versterken van onderzoekvermogens, maar van academische professionele vermogens.

Dan nog zullen jonge onderzoekers onzekerheden en onduidelijkheden ervaren, misschien zelfs meer dan ooit, vanwege de voortgaande ontwikkelingen, maar ook los daarvan. Want het werken aan een $\mathrm{PhD}$-project is mede vanwege alle existentiële dimensies van het promoveren intrinsiek lastig, lees: wreed! Maar dan kunnen de inbedding, begeleiding en vooruitzichten als minder 'wreed' overkomen.

\section{Slot}

Voor de duidelijkheid, ik wil niet de indruk wekken dat jonge onderzoekers geen problemen ervaren en geen lastige keuzen moeten maken, bijvoorbeeld inzake carrièrestappen. En ik wil ook niet de indruk wekken dat er 'niks' aan de hand is, 
bijvoorbeeld als het gaat om de bestuurskunde en publicatiedruk. Er is wel degelijk wat aan de hand. Maar ik denk vooral dat de 'framing' van het probleem preciezer moet zijn, en dat door een gebrekkige framing de problemen eerder groter worden dan kleiner. Bijvoorbeeld omdat van seniors wordt verwacht dat ze een mooie toekomst maken, terwijl ze dat helemaal niet kunnen. En omdat juniors ervan uitgaan dat het nu eindelijk goed wordt geregeld, terwijl ze zelf ook zaken kunnen regelen.

Ik besef overigens ook dat dit veel met context te maken heeft: op welke plek zit je, bij wie in de buurt, zowel persoonlijk als institutioneel? Zit je in de buurt van vakgebieden als psychologie met een strikt academisch regime, of niet? Hoe draait de afdeling of het instituut, zowel organisatorisch als financieel? Zitten de seniors goed in bestuurlijke circuits, lokaal en landelijk? Wie is/zijn je begelei$\operatorname{der}(\mathrm{s})$ ? Ben je onderdeel van een team, of niet? Dat alles maakt verschil. Maar in alle gevallen kunnen we en kun je zelf ook verschil maken; individueel en collectief kunnen we de onzekere en onduidelijke omstandigheden van bestuurskundig onderzoek minder wreed en meer werkbaar maken. 